\title{
KAJIAN STATISTICAL DAN COST EFFICIENCY DALAM PENENTUAN GUGUS SAMPEL BLOK SENSUS TERBAIK (Studi Kasus: Sampling Design Susenas-2015 di Kabupaten Natuna)
}

\author{
Wiwik Andriyani Lestari Ningsih ${ }^{1}$, I Made Arcana ${ }^{2}$ \\ ${ }^{1}$ Badan Pusat Statistik; ${ }^{2}$ Politeknik Statistika STIS \\ e-mail: wiwik.andriyani@bps.go.id, arcana@stis.ac.id
}

DOI: 10.14710/medstat.11.2.93-105

\section{Article Info:}

Received: 26 April 2018

Accepted: 12 February 2019

Available Online: 4 March 2019

Keywords: sampling design, all possible samples, statistical efficiency, cost efficiency

\begin{abstract}
Two aspects of efficiency that should be considered in applying sampling design of a survey are statistical efficiency and cost efficiency. Efficiency in statistical aspect improves precision of estimators obtained by the survey data, whereas efficiency in cost aspect provides an economic survey. The purpose of this researchis to evaluate the both efficiencies in all possible census blocks (CBs) sample setand to identify the best CBs sample set in the 2015 National Socio-Economic Survey (Susenas). Therefore, a computer program for calculating statistical, and cost efficiency aspects was developed in this research to determine the best sampel set of CBs among all possible sampel set of CBs based on sampling design of the 2015 Susenas implemented in Natuna District, Kepulauan Riau Province. The best possible sample set of CBs is determinedby considering statistical efficiency aspect, cost efficiency aspect, as well as combination of those two aspects. The result showed that the best sample set of CBs on statistical efficiency aspect provided the CBs sample set having minimum value of RSE index; evaluation on cost efficiency aspect provided the best CBs sample set having minimum value of total cost esimated using the total score of accessibility index; and evaluation on both efficiency aspects provided the best CBs sample set having minimum value of RSE index and minimum value of total score of accessibility index.
\end{abstract}

\section{PENDAHULUAN}

Sampling design merupakan tahapan penting dari metodologi survei yang mencakup keseluruhan aspek yang meliputi proses penentuan dan pemilihan sampel dalam suatu survei. Survei Sosial Ekonomi Nasional (Susenas) yang merupakan salah satu survey rumah tangga yang secara rutin dilakukan oleh Badan Pusat Statistik (BPS) menerapkan two stages stratified sampling sejak pelaksanaan Susenas 2015, dimana 
stratifikasinya didasarkan pada kombinasi dari status wilayah (perkotaan dan perdesaan) dan tingkat kesejahteraan rumah tangga menggunakan pendekatan indeks kesejahteraan/wealth index (kesejahteraan tinggi, menengah, dan rendah).

Lehtonen dan Pahkinen (2004) mengungkapkan bahwa dalam suatu sampling design terdapat dua aspek efisiensi yang harus dipertimbangkan, yaitu statistical efficiency (efisien pada penduga yang dihasilkan) dan cost efficiency (efisien pada biaya pelaksanaan). Aspek statistical efficiency berhubungan dengan nilai presisi dari suatu penduga yang ditandai dengan nilai sampling variance yang minimum, sementara aspek cost efficiency berkaitan dengan biaya minimum ketika proses pengumpulan data di lapangan. Pada kenyataannya, kedua aspek tersebut bertolak belakang, artinya untuk memperoleh penduga dengan presisi yang baik (statistical efficiency tinggi) diperlukan jumlah sampel yang besar yang pada gilirannya berakibat pada meningkatnya biaya survei (cost efficiency rendah).

Pada tahapan pemilihan sampel blok sensus (BS) dalam sampling design Susenas, perlu dipertimbangkan aspek presisi estimasi indikator pokok dari setiap gugus sampel BS yang kemungkinan terpilih. Gugus sampel BS yang diharapkan adalah gugus sampel yang menunjukkan presisi tinggi, ditandai dengan nilai estimasi relative standard error (RSE) yang relatif kecil. Namun, adanya BS di daerah sulit yang termasuk dalam gugus sampel, berdampak pada tingkat efisiensi biaya operasional pengumpulan data di lapangan yang berpeluang munculnya permintaan pergantian sampel BS akibat beban pendataan yang lebih berat, waktu pendataan yang lebih lama, dan biaya yang lebih besar. Untuk itu gugus sampel BS yang terpilih diharapkan memuat relatif sedikit BS yang berlokasi di daerah yang aksesnya sulit, sehingga dapat mengefisienkan biaya operasional pengumpulan data di lapangan. Oleh karena itu, penelitian ini bertujuan untuk mengkaji statistical efficiency dan cost efficiency dalam penentuan gugus sampel BS yang paling efisien dengan melakukan evaluasi terhadap keseluruhan kandidat gugus sampel BS yang dapat dihasilkan dari sampling design Susenas 2015 dengan wilayah studi kasus di Kabupaten Natuna Provinsi Kepulauan Riau.

\section{TINJAUANPUSTAKA}

\subsection{Statistical Efficiency dalam Pemilihan Gugus Sampel}

Department of Economic and Social Affairs Statistics Division (2005) menyatakan bahwa salah satu ukuran untuk mengukur tingkat presisi dalam suatu survei adalah sampling variance yang merupakan ukuran keragaman dari distribusi sampel suatu penduga yang dihasilkan. Evaluasi terhadap suatu penduga sering kali menggunakan ukuran standard error, yaitu akar kuadrat dari sampling variance. Nilai standard error digunakan untuk mengestimasi besarnya sampling error yang ditampilkan dalam tiga bentuk ukuran yang berbeda, yaitu nilai absolut standard error, relative standard error (RSE), dan confidence intervals (selang kepercayaan).

Salah satu metode penghitungan nilai standard error pada data hasil survei kompleks seperti Susenas menggunakan pendekatan metode linearisasi dengan mengaplikasikan metode perluasan Taylor series. Pendekatan ini secara luas digunakan karena dapat diterapkan pada desain sampel dan statistik secara umum yang merupakan fungsi linear dari statistik yang dihasilkan, seperti rata-rata atau total, dengan koefisien yang diperoleh dari proses diferensiasi pada komponen yang diperlukan. 


\subsection{Cost Efficiency dalam Pemilihan Gugus Sampel}

Cochran (1977) mengungkapkan bahwa salah satu tujuan dari penerapan sampling techniques dalam suatu survei adalah agar tercapai efisiensi pada proses penarikan sampel, penduga yang dihasilkan maupun biaya yang dibutuhkan. Aspek cost efficiency berkaitan dengan kebutuhan biaya pelaksanaan survei yang besarannya dapat ditekan seminimal mungkin. Dalam penghitungan estimasi cost efficiency digunakan pendekatan indikator kategori akses, karena berdasarkan Litman (2015) bahwa accessibility berhubungan dengan kemudahan dalam meraih barang, jasa, aktivitas, dan tujuan, yang secara keseluruhan disebut kesempatan. Dengan kata lain, akses mengacu pada keseluruhan kemampuan seseorang untuk meraih layanan dan aktivitas, dan oleh karenanya waktu dan biaya merupakan komponen yang tidak terpisahkan.

Beberapa faktor umum yang mempengaruhi akses menurut Litman (2015) digunakan dalam penentuan dan pemilihan beberapa variabel yang terdapat dalam data Podes-2014, yaitu:

1. Kondisi perjalanan menggunakan kendaraan bermotor (motor vehicle travel conditions), meliputi kecepatan kendaraan, kemampuan, dan keselamatan dalam berkendara.

2. Kualitas mode pendukung lainnya dalam perjalanan (quality of other modes), meliputi berjalan, bersepeda, peristirahatan publik, kecepatan jasa antar, kesempatan, kenyamanan, kemampuan, dan keselamatan.

3. Koneksi jaringan transportasi (transport network connectivity), meliputi kepadatan jalan, koneksi jalan raya, jarak antar perjalanan, kualitas koneksi antar mode, seperti kenyamanan menuju stasiun transportasi publik.

4. Penggunaan lahan (land use proximity), meliputi pengembangan jalan dan penggabungan jalan.

Berdasarkan variabel-variabel yang telah ditentukan dengan referensi tersebut, selanjutnya dilakukan perhitungan indeks untuk menentukan tingkat kategori akses. Penghitungan indeks kategori akses dilakukan dengan menerapkan Principal Component Analysis (PCA) Polychoric,yang merupakan perluasan dari PCA yang dikembangkan sejak awal abad ke-20 oleh Pearson Hotelling pada tahun 1933 untuk data kategorik (Kolenikov dan Angeles, 2004).

\section{METODE PENELITIAN}

\subsection{Sumber dan Metode Pengumpulan Data}

Data yang digunakan dalam penelitian ini adalah data sekunder yang dihasilkan oleh Badan Pusat Statisik (BPS) dalam bentuk master frame Susenas 2015 di Kabupaten Natuna, Provinsi Kepulauan Riau sebagai dasar dalam pembentukan all possible samples BS untuk penghitungan penimbang; Sensus Penduduk (SP) 2010 untuk penghitungan RSE dan difference; serta Potensi desa (Podes) 2014 untuk dasar penghitungan indeks kategori akses. Struktur data yang digunakan secara lebih rinci dapat dilihat pada Lampiran 1.

Sampling design yang diterapkan pada Susenas 2015 untuk tingkat estimasi kabupaten/kota adalah two stages stratified sampling (Subdit Pengembangan Desain Sensus dan Survei BPS, 2015), dengan tahapan sebagai berikut: 
Tahap 1:

a. Memilih 25\% BS dari populasi yang ada secara probabilitiy proportional to size (PPS) dengan ukuran jumlah rumah tangga hasil SP2010 di setiap strata BS, yang selanjutnya digunakan sebagai sampling frame dalam proses pemilihan BS.

b. Memilih BS sejumlah $n$ sesuai alokasi jumlah BS secara systematic di setiap strata. Pada proses pemilihan BS dibentuk semua kemungkinan gugus sampel (all possible samples) BS. Untuk Kabupaten Natuna, jumlah sampel BSyang telah ditentukan oleh BPS adalah sebanyak 44 BS.

Tahap 2: Memilih 10 rumah tangga berdasarkan hasil pemutakhiran pada BS terpilih secara systematic sampling dengan menerapkan implicit stratification berdasarkan pendidikan kepala rumah tangga.

\subsection{Metode Analisis}

Secara umum, terdapat tiga tahapan yang dilakukan dalam penelitian ini yaitu penyiapan informasi kategori akses, pembentukan all possible samples BS, dan penentuan possible samples BS terbaik. Penyiapan informasi kategori akses merupakan tahapan awal untuk melengkapi informasi pada setiap BS dalam master frame Susenas 2015 sehingga bisa dilakukan penentuan gugus sampel BS terbaik dari aspek cost efficiency. Informasi mengenai kategori akses tersebut dibentuk menggunakan beberapa variabel data Podes 2014. Pembentukan kategori tersebut dilakukan dengan tahapan sebagai berikut:

1. MelakukanpenghitunganindekskategoriaksesdesadenganpendekatananalisisPolychoric Principal Component Analysis (Polychoric PCA) melibatkan enam variabel kategori akses berdasarkan data Podes 2014 untuk menghitung nilai indeks kategori akses (accessibility index) untuk setiap desa dengan menerapkan rumus (1).

$$
I_{g}=\alpha_{g 1 k}+\alpha_{g 2 k}+\ldots+\alpha_{g 6 k}
$$

Keterangan:

$I_{g} \quad: \quad$ indeks akses desa ke-g

$\alpha_{g 1 k}:$ skor untuk desa ke-g variabel pertama kategori ke-k

$\alpha_{g 2 k}:$ skor untuk desa ke-g variabel kedua kategori ke-k

$\alpha_{g 6 k}:$ skor untuk desa ke-g variabel keenam kategori ke-k

2. Membagi seluruh desa menjadi tiga kelompok kategori berdasarkan cutting point nilai kuartil yang dihitung berdasarkan data empiris nilai indeks kategori akses, yaitu

Kategori 1 : tingkat akses mudah (nilai indeks $<$ Q1)

Kategori 2 : tingka akses menengah (nilai indeks antara Q1 dan Q3)

Kategori 3 : tingkat akses sulit (nilai indeks > Q3)

3. Menetapkan setiap kategori wilayah tersebut (1, 2, dan 3) masing-masing dengan skor/bobot1, 2 dan 3, yang digunakan dalam melakukan estimasi biaya kategoria kses pada setiap BS.

Metode sampling yang digunakan untuk membentuk seluruh kemungkinan gugus sampel BS tersebut sesuai dengan metode sampling Susenas 2015. Membentuk seluruh kemungkinan gugus sampel BS dalam penelitian ini membutuhkan data sampling frame BS yang diperoleh dari data master frame BS. Proses pemilihan sampel untuk menghasilkan sampling frame BS tersebut dilakukan BPS menggunakan metode sampling PPS dengan ukuran jumlah rumah tangga. Selanjutnya, berdasarkan sampling frame BS tersebut dilakukan proses pemilihan sampel dengan systematic sampling sehingga menghasilkan all possible sample BS per strata, yang kemudian dilakukan proses kombinasi yang melibatkan seluruh strata untuk memperoleh all possible samples BS. 
Prosedur untuk menentukan gugus sampel BS terbaik dari aspek statistical efficiency didasarkan pada indikator yang tercakup dalam data SP 2010 (data individu dan rumah tangga) yang digabung dengan master frame BS, sehingga bisa dilakukan pemilihan beberapa variabel untuk indikator pendidikan (anggota rumah tangga) dan perumahan (rumah tangga). Data master frame BS yang sudah dilengkapi informasi strata serta beberapa variabel yang dibutuhkan, selanjutnya dikompilasidengan data all possible samples yang telah terbentuk. Data master frame BS selanjutnya digunakan sebagai dasar untuk penghitungan persentase difference dan RSE pada setiap variabel yang telah ditentukan dengan menerapkan formula yang tercantum pada persamaan (2), (3), (4) dan (5). Persamaan tersebut merupakan hasil modifikasi dari rumus umum yang sudah ada (Sharon, 2010).

$$
\begin{aligned}
& \text { persentase difference }=\frac{\mathrm{r}-R}{R} \times 100 \% \\
& \mathrm{r}=\frac{y}{x}=\frac{\sum_{\mathrm{h}} \Sigma_{\mathrm{i}} \Sigma_{\mathrm{j}} w_{h i} y_{h i j}}{\sum_{\mathrm{h}} \sum_{\mathrm{i}} \Sigma_{\mathrm{j}} w_{h i} x_{h i j}}, \quad w_{h i}=\frac{z_{h}}{z_{h i} n_{h}}
\end{aligned}
$$

Keterangan:

$$
\begin{aligned}
& r \quad: \quad \text { rasio untuk karakteristik yang diteliti berdasarkan data sampel } \\
& R \quad \text { : rasio untuk karakteristik yang diteliti berdasarkan data populasi } \\
& y \quad \text { : estimasi total untuk variabel } \mathrm{Y} \\
& x \quad \text { : estimasi total untuk variabel } \mathrm{X} \\
& y_{h i j} \quad: \quad \text { nilai karakteristik variabel Y pada rumah tangga ke-j, BS ke-i dan strata } \\
& \text { ke- } h \\
& x_{h i j} \text { : nilai karakteristik variabel X pada rumah tangga ke-j, BS ke-i dan strata } \\
& \text { ke- } h \\
& w_{h i} \text { : penimbang sampel (sampling weight) strata ke- } h \text { pada BS ke-i } \\
& z_{h i} \quad \text { : total rumah tangga pada BS ke-i, strata ke- } h \\
& z_{h} \quad: \quad \text { total rumah tangga pada strata ke- } h \\
& n_{h} \quad: \text { jumlah sampel BS strata ke- } h \\
& \text { persentase } R S E=\frac{\sqrt{v(r)}}{r} \times 100 \% \\
& \mathrm{v}(r)=\sum_{h}\left(\left(1-f_{h}\right) \frac{n_{h}}{n_{h}-1} \sum_{\mathrm{i}}\left(z_{h i}-\frac{z_{h}}{n_{h}}\right)^{2}\right) \\
& f_{h}=\frac{\mathrm{n}_{\mathrm{h}}}{\mathrm{N}_{\mathrm{h}}}, \quad z_{h i}=\frac{1}{x}\left(y_{h i}-r \cdot x_{h i}\right), \quad z_{h}=\sum_{\mathrm{i}} z_{h i}
\end{aligned}
$$

Keterangan:

$R S E$ : relative standard error untuk setiap variabel

$v(r)$ : sampling variance untuk rasio setiap variabel

$f_{h} \quad$ : sampling fraction BS pada strata ke-h

$N_{h} \quad:$ jumlah populasi BS pada strata ke- $h$

$y_{h i} \quad$ : estimasi total variabel Ypada blok sensus ke-i strata ke- $h$

$x_{h i} \quad$ : estimasi total variabel X pada blok sensus ke-i strata ke- $h$

Dengan menggunakan persentase nilai RSE yang telah dihitung, dilakukan penghitungan nilai indeks untuk setiap kombinasi indikator yang dipilih/ditentukan menggunakan rumus pada persamaan (6).

$$
I_{r s e(i)}=\frac{1}{p} \sum_{\mathrm{j}=1}^{p} \frac{\left(R S E_{i j}-R S E_{j, \min }\right)}{\left(R S E_{j, \max }-R S E_{j, \min }\right)}
$$


Keterangan:

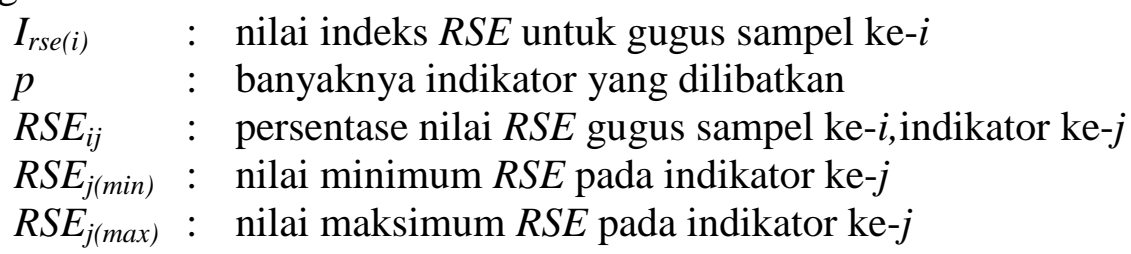

Oleh karena dalam penelitian ini melibatkan empat indikator, maka akan terdapat 15 nilai indeks yang berbeda yang merupakan kombinasi dari empat indikator yang terlibat. Penghitungan indeks tersebut dimaksudkan untuk membuat agregasi dari beberapa indikator yang terlibat ke dalam satu nilai sehingga lebih mudah untuk diperbandingkan.

Prosedur untuk menentukan gugus sampel BS terbaik dari aspek cost efficiency membutuhkan data master frame BS yang disatukandengan data Podes 2014 yang sudah memuat informasi kategori akses sehingga terbentuk master frame BS yang dilengkapi informasi strata dan kategori akses. Master frame BS tersebut kemudian digabungdengan all possible samples yang telah dibentuk, yang siap untuk dihitung nilai estimasi biaya (C) untuk setiap posible samplesBSyang terbentuk.

$$
\mathrm{C}=\frac{3}{2} \sum_{\mathrm{i}=1}^{3}\left(n_{i} \cdot c_{i}\right) ; i=1,2,3
$$

Keterangan:

$$
\begin{aligned}
& C \text { : estimasi total biaya menggunakan skor kategori akses } \\
& n_{i}: \text { banyaknya sampelBS dengan kategori akses ke- } i \\
& c_{i}: \text { estimasi biaya untuk kategori akses ke- } i
\end{aligned}
$$

Rumus (7) merupakan modifikasi dari bentuk umum dalam menghitung total biaya, yaitu $C=n C_{1}+n m C_{2}$ ( $n$ : banyaknya sampel blok sensus; $m$ : banyaknya sampel rumah tangga; $C_{1}$ : biaya antar blok sensus; $C_{2}$ : biaya dalam blok sensus). Aliaga dan Ren (2006) mengungkapkan bahwa secara umum perbandingan $C_{1} / C_{2}$ bernilai 20. Komponen $C_{1}$ dalam penelitian ini merupakan pendekatan untuk biaya antar BS (skor kategori akses).

Penentuan gugus sampel BS terbaik dari aspek statistical efficiency didasarkan pada indikator yang telah ditetapkan yang memiliki nilai indeks RSE terkecil. Sedangkan, penentuan gugus sampel BS terbaik dari aspek cost efficiency didasarkan pada nilai estimasi terkecil untuk total biaya dengan mempertimbangkan skor kategori akses $(C)$ gugus sampel BS yang terbentuk. Dengan demikian, gugus sampel BS yang memuat BS dengan kategori akses mudah paling banyak akan ditetapkan sebagai gugus sampel BS terbaik. Lebih jauh lagi, penentuan gugus sampel BS terbaik untuk gabungan aspek statistical dan cost efficiency menggunakan nilai indeks RSE yang terkecil untuk gugus sampel BS tersebut, sekaligus juga menghasilkan estimasi total biaya yang relatif kecil pada skor kategori akses.

\section{HASIL DAN PEMBAHASAN}

Rancangan arsitektur aplikasi komputer yang dihasilkan untuk melakukan proses pemilihan gugus sampel BS terbaik ditampilkan pada Gambar 1 yang terdiri dari: a) Microsoft Visual Studio 2010 (C\#) dengan Framework.NET yang digunakan untuk merancang Graphical User Interface (GUI) dari aplikasi yang dibuat, b) R 3.2.0 yang digunakan untuk membuat fungsi-fungsi penghitungan statistik dari aplikasi, c) Connector R.NET yang digunakan sebagai penghubung antara R dengan C\#; dan d) Stata yang digunakan sebagai alat bantu dalam penyiapan informasi kategori akses. 


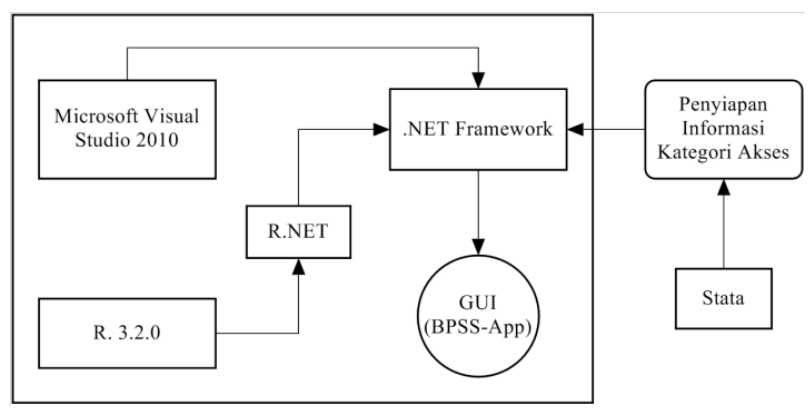

Gambar 1 Rancangan Arsitektur Aplikasi

Informasi kategori akses atau variabel akses dalam penelitian ini diperoleh dengan menggunakan bantuan Stata yang syntax-nya dibuat sendiri menggunakan pendekatan Polychoric PCA. Hasil yang diperoleh bisa dilihat pada Gambar 1. Dari gambar tersebut dapat dilihat polychoric correlation antar variabel, eigen value, proporsi varians yang dijelaskan tiap PCA yang terbentuk menggunakan enam variabel yang digunakan (terdapat di Lampiran 1, serta score dari tiap kategori dari variabel yang digunakan.Dalam pembentukan indeks akses dibutuhkan nilai penimbang yang diperoleh dari nilai score principal component yang pertama dengan alasan bahwa principal component yang pertama mempunyai kontribusi terbesar dalam menjelaskan variabilitas data. Dari output tersebut, dapat ditunjukkan bahwa besarnya variabilitas yang bisa dijelaskan oleh principal component yang pertama relatif besar yaitu 52,44\% dengan eigen value sebesar 3,15.

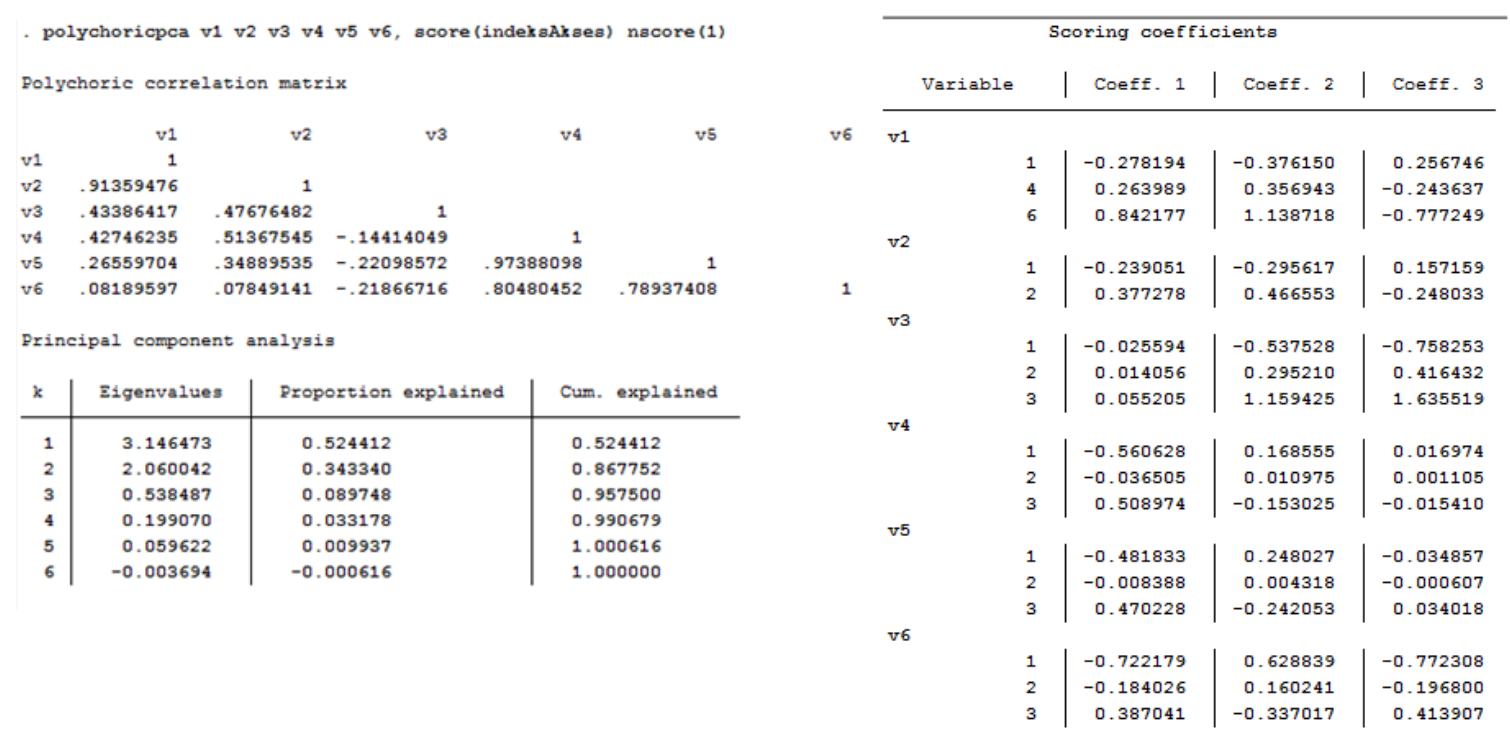

Gambar 2 Output Saat Pembentukan Tambahan Data Podes-2014 Menggunakan Stata (Informasi Kategori Akses/Variabel Akses)

\subsection{Gugus Sampel BS Terbaik dari Aspek Statistical Efficiency}

Output yang dihasilkan dari aplikasi dalam menentukan gugus sampel BS terbaik daria spek statistical efficiency adalah berupa daftar ID dari BS yang tercakup dalam lima gugus sampel BS dengan nilai indeks RSE terkecil untuk setiap kombinasi dari empat indikator yang terlibat dilengkapi dengan grafik distribusi dari all possible samples yang 
dibentuk. Nilai indeks RSE pada lima gugus sampel BS terbaik dari aspek statistical efficiency untuk setiap kombinasi empat indikator yang terlibat, ditampilkan pada Tabel 1.

Tabel 1 Nilai Indeks RSE Lima Gugus Sampel BS Terbaik dari Aspek Statistical Efficiency Berdasarkan Indikator yang Ditentukan

\begin{tabular}{clccccc}
\hline No & Indikator & PS-1 & PS-2 & PS-3 & PS-4 & PS-5 \\
& & & & & & \\
\hline $\mathbf{( 1 )}$ & \multicolumn{1}{c}{$\mathbf{( 2 )}$} & $\mathbf{( 3 )}$ & $\mathbf{( 4 )}$ & $\mathbf{( 5 )}$ & $\mathbf{( 6 )}$ & $\mathbf{( 7 )}$ \\
1 & R1 & 0,0000 & 0,0096 & 0,0129 & 0,0224 & 0,0233 \\
2 & R2 & 0,0000 & 0,0036 & 0,0139 & 0,0164 & 0,0211 \\
3 & R3 & 0,0000 & 0,0044 & 0,0272 & 0,0274 & 0,0290 \\
4 & R4 & 0,0000 & 0,0025 & 0,0088 & 0,0095 & 0,0121 \\
5 & R1, R2 & 0,1910 & 0,0254 & 0,0262 & 0,0317 & 0,0578 \\
6 & R1, R3 & 0,0267 & 0,0441 & 0,0510 & 0,0566 & 0,0684 \\
7 & R1, R4 & 0,2847 & 0,2895 & 0,2902 & 0,2930 & 0,2997 \\
8 & R2, R3 & 0,0356 & 0,0471 & 0,0471 & 0,0583 & 0,0614 \\
9 & R2, R4 & 0,0209 & 0,0286 & 0,0600 & 0,0619 & 0,0715 \\
10 & R3, R4 & 0,3810 & 0,3891 & 0,3938 & 0,3991 & 0,4071 \\
11 & R1, R2, R3 & 0,0400 & 0,0548 & 0,0587 & 0,0750 & 0,0830 \\
12 & R1, R2, R4 & 0,2005 & 0,2039 & 0,2106 & 0,2222 & 0,2260 \\
13 & R2, R3, R4 & 0,2606 & 0,2660 & 0,2762 & 0,2833 & 0,2878 \\
14 & R1, R3, R4 & 0,2703 & 0,2710 & 0,2835 & 0,2859 & 0,2870 \\
15 & R1, R2, R3, R4 & 0,2041 & 0,2126 & 0,2194 & 0,2222 & 0,2300 \\
\hline
\end{tabular}

Perbandingan nilai RSE berdasarkan indikator aspek statistical efficiency dengan nilai RSE gugus sampel terpilih pada Susenas 2015 disertai informasi ranking dalam all possible samples ditampilkan pada Tabel 2. Terlihat bahwa nilai RSE untuk indikator terpilih yang dihasilkan pada Susenas 2015 masih berada dalam jangkauan nilai RSE, walaupun nilai RSE yang diberikan tidak minimum. Hal ini menunjukkan bahwa kualitas data hasil Susenas melalui pengendalian sampling error masih memungkinkan untuk ditingkatkan dengan memilih gugus sampel BS yang memiliki statistical efficiency yang tinggi.

Tabel 2 Perbandingan Nilai RSE Susenas Maret-2015 dengan All Possible Samples Aspek Statistical Efficiency Berdasarkan Empat Indikator

\begin{tabular}{cccccc}
\hline \multirow{2}{*}{ No } & Indikator & \multicolumn{4}{c}{ Nilai RSE } \\
\cline { 3 - 6 } & & \multicolumn{2}{c}{ All Possible Samples } & \multicolumn{2}{c}{ Susenas Maret 2015 } \\
& & Min & Max & (Urutan) \\
$\mathbf{( 1 )}$ & $\mathbf{( 2 )}$ & $\mathbf{( 3 )}$ & $\mathbf{( 4 )}$ & $\mathbf{( 5 )}$ & \\
1 & R1 & 6,4274 & 9,3399 & 6,9017 & $(48)$ \\
2 & R2 & 3,6426 & 5,0053 & 4,7183 & $(97)$ \\
3 & R3 & 6,8616 & 10,1896 & 7,6529 & $(55)$ \\
4 & R4 & 5,4101 & 8,3465 & 7,5362 & $(106)$ \\
\hline
\end{tabular}




\subsection{Gugus Sampel BS Terbaik dari Aspek Cost Efficiency}

Output aplikasi berupa daftar ID dari BSyang dilengkapi nilai total untuk kategori akses yang minimum sebagai estimasi biaya total pada lima gugus sampel BS terbaik dari aspek cost efficiency dapat dilihat pada Tabel 3. Dari tabel tersebut juga bisa dilihat berapa jumlah gugus sampel untuk tiap lima gugus sampel blok sensus terbaik yang memiliki nilai estimasi total cost sama (tabel 3 baris 2), yang memberikan peluang lebih besar untuk memilih gugus sampel BS yang digunakan dalam survei.

Tabel 3 Nilai Total Kategori Akses untuk Lima Gugus Sampel BS Terbaik dari Aspek Cost Efficiency

\begin{tabular}{ccccccc}
\hline No & Keterangan & PS-1 & PS-2 & PS-3 & PS-4 & PS-5 \\
\hline $\mathbf{( 1 )}$ & $\mathbf{( 2 )}$ & $\mathbf{( 3 )}$ & $\mathbf{( 4 )}$ & $\mathbf{( 5 )}$ & $\mathbf{( 6 )}$ & $\mathbf{( 7 )}$ \\
1 & $\begin{array}{l}\text { Total Kategori Akses } \\
\text { (Nilai estimasi total cost) }\end{array}$ & 115,5 & 117 & 118,5 & 120 & 121,5 \\
2 & Jumlah possible samples & 1 & 3 & 5 & 7 & 10 \\
\hline
\end{tabular}

Keterangan: PS = Possible Samples

Perbandingan lima gugus sampel BS terbaik yang dihasilkan aplikasi terhadap gugus sampel BS yang terpilih pada Susenas 2015 ditampilkan pada Tabel 4. Terlihat bahwa gugus sampel BS Susenas 2015 tidak termasuk dalam lima gugus sampel BS terbaik dari aspek costefficiency yang dihasilkan oleh aplikasi. Kondisi ini memperlihatkan bahwa cost efficiency gugus sampel BS pada Susenas dapat dioptimalkan dengan memilih gugus sampel BS melalui aplikasi yang dikembangkan dalam penelitian ini.

Tabel 4 Perbandingan Nilai Estimasi Total Cost Kategori Akses Susenas Maret-2015 dengan All Possible Samples Aspek Cost Efficiency

\begin{tabular}{ccccc}
\hline No & Keterangan & \multicolumn{2}{c}{ All Possible Samples } & Susenas Maret-2015 \\
\cline { 3 - 4 } & & $\mathbf{M i n}$ & $\mathbf{M a x}$ & (Urutan) \\
$\mathbf{( 1 )}$ & $\mathbf{( 2 )}$ & $\mathbf{( 3 )}$ & $\mathbf{( 4 )}$ & $\mathbf{( 5 )}$ \\
1 & Nilai estimasi total cost & 115,5 & 136,5 & $127,5(9)$ \\
2 & Jumlah possible samples & 1 & 1 & 18 \\
\hline
\end{tabular}

\subsection{Gugus Sampel BS Terbaik untuk KeduaAspek (Statistical dan Cost Efficiency)}

Output berupa daftar ID dari BS dilengkapi nilai indeks RSE dan nilai estimasi biaya total (cost) untuk lima gugus sampel BS terbaik dari aspek kombinasi antara statistical dan cost efficiency ditampilkan pada Lampiran 2. Sementara, perbandingan dengan gugus sampel BS yang terpilih pada Susenas 2015 dapat dilihat pada Tabel 5. Gugus sampel BS yang dihasilkan dengan bantuan aplikasi menunjukan tingkat efisiensi yang lebih tinggi dibandingkan gugus sampel BS yang terpilih pada Susenas 2015 untuk setiap indikator yang digunakan. 
Tabel 5 Perbandingan Nilai RSE dan Estimasi Cost Susenas Maret-2015 dengan All Possible Samples Aspek Kombinasi antara Statistical Efficiency dan Cost Efficiency

\begin{tabular}{|c|c|c|c|c|c|c|c|c|}
\hline \multirow[t]{3}{*}{ No } & \multirow[t]{3}{*}{ Indikator } & \multicolumn{7}{|c|}{ Nilai RSE (Estimasi Cost) } \\
\hline & & \multicolumn{4}{|c|}{ All Possible Samples } & \multirow{3}{*}{\multicolumn{3}{|c|}{$\begin{array}{c}\text { Susenas Maret-2015 } \\
\text { [Urutan] }\end{array}$}} \\
\hline & & & & $M$ & & & & \\
\hline (1) & (2) & & & ( & & & & \\
\hline 1 & R1 & 6,4274 & (123) & 9,3399 & $(130,5)$ & 6,9017 & $(127,5)$ & [48] \\
\hline 2 & R2 & 3,6426 & (135) & 5,0053 & (123) & 4,7183 & $(127,5)$ & [97] \\
\hline 3 & R3 & 6,8616 & (123) & 10,1896 & (126) & 7,6529 & $(127,5)$ & [55] \\
\hline 4 & R4 & 5,4101 & $(130,5)$ & 8,3465 & (123) & 7,5362 & $(127,5)$ & [106] \\
\hline
\end{tabular}

\section{KESIMPULAN}

Berdasarkan hasil yang telah diuraikan sebelumnya, kesimpulan yang diperoleh dari penelitian ini adalah sebagai berikut:

1. Aplikasi yang dikembangkan memberikan gugus sampel BS alternatif yang dapat meningkatkan efisiensi pelaksanaan survei, baik pada aspek statistical efficiency yang ditunjukkan dengan nilai indeks $R S E$ yang minimum berdasarkan indikator yang dapat ditentukan oleh pengguna aplikasi, serta pada aspekcost efficiencyy ang ditunjukkan dengan nilai estimasi cost yang minimum berdasarkan kategori akses.

2. Evaluasi terhadap gugus sampel BS dalam Susenas 2015 memperlihatkan bahwa efisiensi hasil survei dapat ditingkatkan dengan pemilihan gugus sampel BS yang yang dapat mengoptimalkan statistical dan cost efficiency, yang pada gilirannya akan meningkat kualitas data hasil survei yang dilakukan.

\section{DAFTAR PUSTAKA}

Aliaga, A. dan Ren, R. 2006. Cluster Optimal Size for Demographic and Health Surveys.: ORC Macro, Inc., United States.

Badan Pusat Statistik (BPS). Pendataan Potensi Desa (Podes) 2014 dan Sensus Penduduk 2010. URL: http://sirusa.bps.go.id

Subdit Pengembangan Desain Sensus dan Survei BPS. 2015. Kumpulan Metodologi Sensus dan Survei Tahun 2015. Badan Pusat Statistik, Jakarta.

Cochran, W. G. 1977. Sampling Techniques. John Wiley \& Sons, Ltd., England.

Department of Economic and Social Affairs Statistics Division. 2005. Designing Household Survey Samples: Practical Guidelines. United Nations (UN), New York.

Kolenikov, S. dan Angeles, G. 2014. The Use of Discrete Data in Principal Component Analysis for Socio-Economic Status Evaluation. URL: http://tinyurl.com/nf9qkqq

Lehtonen, R. dan Pahkinen, E. 2004. Practical Methods for Design and Analysis of Complex Surveys (2nd ed). John Wiley \& Sons, Ltd., England.

Litman, T. 2015. Evaluating Accesibility for Transportation Planning. URL: http://www.vtpi.org/access.pdf 
United Nations Development Programme (UNDP). 2006. ICT and Human Development: Towards Building a Composite Index for Asia. Elsevier. New Delhi.

Sharon, L. L. 2010. Sampling: Design and Analysis (2nd ed). Nelsen Education, Ltd., Canada.

Supranto, J. 2007. Teknik Sampling: Untuk Survey dan Eksperimen. Rineka Cipta, Jakarta.

Verma, V. 2013. Sampling Elusive Populations: Applications to Studies of Child Labour. International Labour Organization (ILO), Geneva. 
Lampiran 1 Jenis dan Manfaat Data dalam Pembentukan All Possible Samples Blok Sensus serta Variabel yang Digunakan

\begin{tabular}{|c|c|c|c|c|}
\hline No & Jenis Data & $\begin{array}{c}\text { Manfaat dalam } \\
\text { Pembentukan All Possible } \\
\text { Samples Blok Sensus } \\
\end{array}$ & Variabel & Keterangan Variabel \\
\hline (1) & (2) & (3) & (4) & (5) \\
\hline 1 & $\begin{array}{l}\text { Master Frame } \\
\text { Susenas-2015 (blok } \\
\text { sensus) [type: .dbf] }\end{array}$ & $\begin{array}{l}\text { Penghitungan penimbang } \\
\text { (sampling weight) }\end{array}$ & $\begin{array}{l}\text { BSC1_RT } \\
\text { STRATA_SSN } \\
\text { FRM180RB }\end{array}$ & $\begin{array}{l}\text { Kode blok sensus } \\
\text { Strata Susenas } \\
\text { Blok sensus yang terpilih menjadi sampling frame }\end{array}$ \\
\hline 2 & $\begin{array}{l}\text { SP-2010 (art dan } \\
\text { ruta) [type: .dbf] }\end{array}$ & $\begin{array}{l}\text { Penghitungan } R S E \text { dan } \\
\text { difference untuk evaluasi dari } \\
\text { aspek statistical efficiency. }\end{array}$ & $\begin{array}{l}\text { R213 (kode 3) } \\
\text { R214A (kode 2) } \\
\text { R404 (kode 5) } \\
\text { R406 (kode 4) }\end{array}$ & $\begin{array}{l}\text { Ijazah/STTB tertinggi: Tamat SLTP/MTs/sederajat [R2] } \\
\text { Tidak dapat membaca dan menulis huruf latin [R1] } \\
\text { Bahan bakar utama untuk memasak sehari-hari: kayu [R4] } \\
\text { Fasilitas tempat buang air besar: tidak ada [R3] }\end{array}$ \\
\hline 3 & $\begin{array}{l}\text { Podes-2014 (desa) } \\
\text { [type: .dta] }\end{array}$ & $\begin{array}{l}\text { Pembentukan kategori akses } \\
\text { sebagai dasar penghitungan } \\
\text { cost untuk evaluasi dari aspek } \\
\text { cost efficiency. }\end{array}$ & $\begin{array}{l}\text { R306A \& R1002B_K2 } \\
\text { R1002B_K7 } \\
\text { R1001A } \\
\text { R1001C1 } \\
\text { R1001C2 } \\
\text { R1001C3 }\end{array}$ & $\begin{array}{l}\text { Keberadaan kantor kepala desa/lurah \& Jarak tempuhnya } \\
\text { ke kantor bupati/ walikota. } \\
\text { Biaya transportasi ke kantor bupati/ walikota. } \\
\text { Lalu lintas dari dan ke desa/kelurahan. } \\
\text { Keberadaan angkutan umum. } \\
\text { Operasional angkutan umum yang utama. } \\
\text { Jam operasi angkutan umum yang utama. }\end{array}$ \\
\hline
\end{tabular}

Sumber: Badan Pusat Statistik (BPS) 
Lampiran 2. Nilai Indeks RSE dan Estimasi Total Cost Lima Gugus Sampel Blok Sensus Terbaik dari Aspek Kombinasi antara Statistical dan Cost Efficiency

\begin{tabular}{|c|c|c|c|c|c|c|c|c|c|c|c|}
\hline \multirow{2}{*}{$\begin{array}{l}\text { No } \\
\text { (1) }\end{array}$} & \multirow{2}{*}{$\begin{array}{c}\text { Indikator } \\
\text { (2) }\end{array}$} & \multicolumn{2}{|c|}{ PS-1 } & \multicolumn{2}{|c|}{ PS-2 } & \multicolumn{2}{|c|}{ PS-3 } & \multicolumn{2}{|c|}{ PS-4 } & \multicolumn{2}{|c|}{ PS-5 } \\
\hline & & $\begin{array}{c}\text { Stat } \\
\text { (3) }\end{array}$ & $\begin{array}{c}\text { Cost } \\
(4)\end{array}$ & $\begin{array}{l}\text { Stat } \\
(5)\end{array}$ & $\begin{array}{c}\text { Cost } \\
\text { (6) }\end{array}$ & $\begin{array}{c}\text { Stat } \\
(7)\end{array}$ & $\begin{array}{c}\text { Cost } \\
(8)\end{array}$ & $\begin{array}{c}\text { Stat } \\
(9)\end{array}$ & $\begin{array}{l}\text { Cost } \\
\text { (10) }\end{array}$ & $\begin{array}{l}\text { Stat } \\
\text { (11) }\end{array}$ & $\begin{array}{l}\text { Cost } \\
\text { (12) }\end{array}$ \\
\hline 1 & R1 & 0,0000 & 123,0 & 0,0096 & 124,5 & 0,0129 & 129,0 & 0,0224 & 120,0 & 0,0233 & 130,5 \\
\hline 2 & $\mathrm{R} 2$ & 0,0000 & 135,0 & 0,0036 & 129,0 & 0,0139 & 133,5 & 0,0164 & 127,5 & 0,0211 & 133,5 \\
\hline 3 & R3 & 0,0000 & 123,0 & 0,0044 & 126,0 & 0,0272 & 121,5 & 0,0274 & 129,0 & 0,0290 & 124,5 \\
\hline 4 & $\mathrm{R} 4$ & 0,0000 & 130,5 & 0,0025 & 132,0 & 0,0088 & 126,0 & 0,0095 & 132,0 & 0,0121 & 133,5 \\
\hline 5 & R1, R2 & 0,1910 & 129,0 & 0,0254 & 127,5 & 0,0262 & 135,0 & 0,0317 & 133,5 & 0,0578 & 126,0 \\
\hline 6 & R1, R3 & 0,0267 & 126,0 & 0,0441 & 121,5 & 0,0510 & 132,0 & 0,0566 & 127,5 & 0,0684 & 127,5 \\
\hline 7 & R1, R4 & 0,2847 & 129,0 & 0,2895 & 123,0 & 0,2902 & 133,5 & 0,2930 & 127,5 & 0,2997 & 132,0 \\
\hline 8 & R2, R3 & 0,0356 & 126,0 & 0,0471 & 123,0 & 0,0471 & 132,0 & 0,0583 & 129,0 & 0,0614 & 124,5 \\
\hline 9 & R2, R4 & 0,0209 & 132,0 & 0,0286 & 130,5 & 0,0600 & 126,0 & 0,0619 & 133,5 & 0,0715 & 124,5 \\
\hline 10 & R3, R4 & 0,3810 & 126,0 & 0,3891 & 129,0 & 0,3938 & 132,0 & 0,3991 & 135,0 & 0,4071 & 127,5 \\
\hline 11 & R1, R2, R3 & 0,0400 & 126,0 & 0,0548 & 132,0 & 0,0587 & 129,0 & 0,0750 & 135,0 & 0,0830 & 124,5 \\
\hline 12 & $\mathrm{R} 1, \mathrm{R} 2, \mathrm{R} 4$ & 0,2005 & 133,5 & 0,2039 & 127,5 & 0,2106 & 132,0 & 0,2222 & 126,0 & 0,2260 & 135,0 \\
\hline 13 & R2, R3, R4 & 0,2606 & 129,0 & 0,2660 & 135,0 & 0,2762 & 126,0 & 0,2833 & 132,0 & 0,2878 & 127,5 \\
\hline 14 & R1, R3, R4 & 0,2703 & 126,0 & 0,2710 & 129,0 & 0,2835 & 135,0 & 0,2859 & 132,0 & 0,2870 & 124,5 \\
\hline 15 & R1, R2, R3, R4 & 0,2041 & 129,0 & 0,2126 & 135,0 & 0,2194 & 126,0 & 0,2222 & 127,5 & 0,2300 & 132,0 \\
\hline
\end{tabular}

Keterangan: PS = Possible Samples; Stat = Nilai Indeks RSE; Cost = Nilai Estimasi Total Cost 